\title{
Sistem Pendukung Keputusan untuk Penyakit Sapi Berbasis Android
}

\author{
Muhammad Miftakhul Jannan, Heru Supriyono \\ Teknik Informatika \\ UMS \\ Surakarta, Indonesia \\ Miftakhul28@gmail.com
}

\begin{abstract}
Abstraksi- Sapi merupakan salah satu hewan ternak yang paling banyak dipelihara oleh masyarakat Indonesia. Hal ini dikarenakan oleh banyaknya bagian tubuh sapi yang dapat dimanfaatkan, khususnya untuk bahan pangan seperti daging, kulit dan juga susu sapi. Namun dengan banyaknya populasi sapi yang ada, meningkat pula potensi terjangkitnya penyakit pada tubuh sapi khususnya untuk penyakit yang menular. Hal ini kurang diperhatikan oleh peternak sapi dan dapat menyebabkan berkurangnya produktifitas pada peternakan sapi. Berdasarkan permasalahan tersebut penulis bertujuan untuk menghasilkan sistem pendukung keputusan berbasis android yang dapat menganalisis gejala-gejala penyakit yang diderita oleh sapi. Metode alur penelitian yang digunakan sistem pendukung keputusan ini menerapkan metode forward chaining. Sistem pendukung keputusan ini dibangun dengan menggunakan bahasa pemrograman java dalam perangkat lunak Android Studio 3.0.1. Pengujian aplikasi dengan user dan seorang pakar memberikan validitas yang tinggi. Fitur yang berada dalam sistem dapat berfungsi sesuai dengan harapan peneliti berdasarkan pengujian black box. Sistem ini mampu diterima dengan baik oleh user berdasarkan pengujian user acceptance test dengan nilai rata - rata persentase $80.6 \%$.
\end{abstract}

Katakunci- android; forward chaining; java; sapi, sistem pendukung keputusan

\section{Pendahuluan}

Sapi menjadi komoditi utama bahan pangan di Indonesia. Sapi dapat dimanfaatkan dalam berbagai hal, mulai dari daging, kulit, tulang, susu, hingga kotoran sapi sehingga penjualan sapi semakin meningkat secara signifikan setiap tahunnya. Menurut data produksi daging sapi dalam negeri tahun 2018 sebesar 403.668 ton sedangkan perkiraan kebutuhan daging sapi dalam negeri tahun 2018 sebesar 663.290 ton.

Sapi dapat dipelihara secara individual di rumah maupun berkelompok dalam peternakan. Sapi juga tidak terlalu susah dipelihara, terbukti dengan banyaknya peternak sapi di Indonesia. Meskipun mudah dipelihara, tidak sedikit pula penyakit yang sering menyerang sapi. Menurut Yulianto dan Saparinto (2014), penyebab penyakit pada sapi dapat berasal dari bakteri, virus, cacing, jamur, dan lain-lain.

Selama ini peternak sapi kurang mementingkan gejalagejala penyakit yang terjadi pada tubuh sapi mereka sehingga menyebabkan kelalaian yang berakibat akan terjangkitnya penyakit menular antar sapi yang mereka miliki dan dapat mengakibatkan kematian. Selain itu faktor ekonomi juga menyebabkan enggannya para peternak untuk memeriksakan kesehatan sapi kedokter hewan.Penyakit sapi tidak hanya berakibat pada tubuh sapi namun juga dapat mempengaruhi kesehatan lingkungan bahkan berakibat fatal pada manusia. Oleh sebab inilah para peternak sapi harus mengetahui secara pasti penyakit apa yang menyerang sapi mereka dengan mengenal gejala-gejala yang terjadi sehingga peternak sapi dapat merawat dan mengobati penyakit sapi tersebut.

Sistem pendukung keputusan sudah banyak digunakan disegala bidang dari bidang perusahaan, bidang kesehatan sampai bidang peternakan, contoh penelitian yang dilakukan oleh Handayani (2017) sistem pendukung keputusan pemilihan karyawan berprestasi dengan metode profile matching pada PT.Sarana Inti Persada (SIP). Menurut Supriyono dan Sari (2015) alternative untuk mendapatkan solusi yaitu dengan menggunakan algoritma sistem pendukung keputusan yang sudah diterapakan pada pemilihan rumah tinggal dengan metode weighted product.

Berdasarkan permasalahan diatas, penulis bertujuan untuk membangun sistem pendukung keputusan untuk membantu peternak sapi mengetahui penyakit apa yang menyerang pada tubuh sapi mereka berdasarkan gejala yang terjadi. Sehingga ketika peternak sapi mengetahui kemungkinan penyakit yang memyerang pada sapi mereka, peternak akan mendapatkan informasi solusi untuk penanganan yang harus mereka lakukan untuk menyembuhkan sapi tersebut. Sistem ini menggunakan metode forward chaining. Menurut Katoua(2014) metode forward chaining akan menghasilkan data baru dengan cara sederhana dan penerapan langsung suatu aturan dengan cepat. 
Dengan adanya sistem pendukung keputusan ini diharapkan para peternak sapi lebih mengenal gejala, jenis penyakit serta cara penanganan penyakit pada sapi, sehingga peternakan sapi mereka lebih produktif tanpa adanya serangan penyakit yang menular pada sapi.

\section{Metode}

Metode yang digunakan adalah forward chaining yaitu pelacakan kedepan. Menurut Kapoor dan Bahl (2016) forward chaining dimulai dengan mengumpulkan fakta dengan menerapkan aturan untuk menemukan semua kemungkinan kesimpulan.Metode forward chaining sudah banyak digunakan dalam diagnosa penyakit, contoh Rohman dan Supriyono (2018) sistem pakar diagnosa penyakit ikan lele berbasis android dan penelitian yang dilakukan oleh Hidayat dan Gumilang (2017) sistem pakar diagnosis penyakit yang disebabkan oleh rokok dengan metode forward chaining.Untuk alur diagram akan dijelaskan pada gambar 1 .

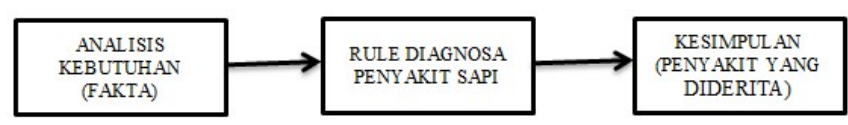

Gambar 1. Alur diagram forward chaining.

\section{A. Analisis Kebutuhan}

Terdapat beberapa golongan sapi di Indonesia yaitu sapi pedaging dan sapi perah. Dalam sistem ini tidak terlepas pengetahuan serta informasi yang terperinci dari sumber, yaitu pakar kesehatan sapi, kelompok peternak sapi serta buku yang merujuk tentang kesehatan sapi. Maka dari itu pembahasan penyakit sapi akan jelas karena tidak terlepas dari pakar kesehatan sapi itu sendiri.

Sistem pendukung keputusan sering digunakan di mobile dan desktop. Dalam hal ini sistem akan dibangun pada perangkat mobile dikarenakan kebanyakan peternak sapi jarang memiliki perangkat desktop akan tetapi lebih banyak mempunyai dan menggunakan mobile dalam hal ini handphone.

Perangkat keras yang digunakan untuk membuat dan perancangan aplikasi yaitu Intel ${ }^{\circledR}$ Core $^{\mathrm{TM}}$ i3 $\mathrm{CPU}, 1,80 \mathrm{GHz}$, RAM 6 GB, dan Hardisk 500 GB. Perangkat lunak yang digunakan untuk membuat dan perancangan aplikasi yaitu Sistem Operasi Windows 8(64 bit), CorelDRAW X8, dan Android Studio 3.0.1. Peralatan pendukung agar sistem pendukung keputusan yaitu handphone minimal dengan sistem operasi android 4.0.3 (icecreamsandwich).

\section{B. Perancangan Sistem Pendukung Keputusan}

Tahap ini terdapat rancangan dasar serta aturan agar tujuan dari sistem pendukung keputusan dapat berjalan.

1) Menentukan Parameter Jenis Penyakit pada Sapi.

Pada tahap ini data yang digunakan adalah data penyakit sapi dari hasil wawancara dengan dokter hewan dan kelompok peternak sapi serta mencari informasi di dalam buku cetak yang disusun oleh Yulianto dan Saparinto (2014). Hasil data daftar penyakit sapi akan dijelaskan pada Tabel 1 .
TABEL I. DAFTAR PENYAKIT SAPI

\begin{tabular}{|l|c|}
\hline Id penyakit & Nama penyakit \\
\hline PS01 & Tuberkolosis \\
\hline PS02 & Antraks \\
\hline PS03 & Radang paha \\
\hline PS04 & Brucellosis \\
\hline PS05 & Leptosirosis \\
\hline PS06 & Vibriosis \\
\hline PS07 & Endometritis \\
\hline PS08 & Mastitis \\
\hline PS09 & Penyakit jamur \\
\hline PS10 & Pneumonia \\
\hline PS11 & IBR \\
\hline PS12 & BVD \\
\hline PS13 & Ngorok \\
\hline PS14 & \\
\hline
\end{tabular}

\section{2) Menentukan Parameter Jenis Gejala Penyakit pada} Sapi.

Pada tahap ini data yang digunakan adalah data gejala penyakit sapi dari hasil wawancara dengan dokter hewan dan kelompok peternak sapi serta mencari informasi di dalam buku cetak yang disusun oleh Yulianto dan Saparinto (2014). Hasil data daftar penyakit sapi akan dijelaskan pada tabel 2.

TABel II. DAFtar GeJala PENYAKIT SAPI

\begin{tabular}{|c|c|}
\hline ID gejala & Nama gejala \\
\hline GPS01 & Demam \\
\hline GPS02 & Lesu \\
\hline GPS03 & Keguguran saat hamil \\
\hline GPS04 & Sulit buang kotoran \\
\hline GPS05 & Nafsu makan berkurang \\
\hline GPS06 & Paha, bahu, leher terlihat membengkak \\
\hline GPS07 & Alat kelamin bengkak \\
\hline GPS08 & Susah hamil \\
\hline GPS09 & Dubur membengkak \\
\hline GPS10 & Ambing bengkak / luka \\
\hline GPS11 & Batuk \\
\hline GPS12 & Napas meningkat \\
\hline GPS13 & Gusi tampak merah, kering, dan panas \\
\hline GPS14 & Berat badan menurun \\
\hline GPS15 & Leleran di vulva \\
\hline GPS16 & Suara ngorok \\
\hline GPS17 & Sesak napas \\
\hline GPS18 & Bulu rontok \\
\hline
\end{tabular}

\section{3) Membuat Basis Pengetahuan}

Dari hasil wawancara dengan dokter hewan dan kelompok peternak sapi serta mencari informasi di dalam buku cetak yang disusun oleh Yulianto dan Saparinto (2014). Diperoleh basis pengetahuan disusun dengan menggunakan metode forward chaining maka didapatkan 14 aturan atau rule yang akan dijelaskan pada Tabel 3. 
TABEL III. ATURAN INFERENSI

\begin{tabular}{|c|c|}
\hline No. & Aturan \\
\hline A01 & IF GPS02 \& GPS03 THEN PS01 \\
\hline A02 & IF GPS01 \& GPS02 \& GPS04 \& GPS05 THEN PS02 \\
\hline A03 & IF GPS05 \& GPS06 THEN PS03 \\
\hline A04 & IF GPS05 \& GPS07 THEN PS04 \\
\hline A05 & IF GPS01 \& GPS03 \& GPS05 THEN PS05 \\
\hline A06 & IF GPS03 \& GPS08 THEN PS06 \\
\hline A07 & IF GPS01 \& GPS09 THEN PS07 \\
\hline A08 & IF GPS01 \& GPS05 \& GPS10 THEN PS08 \\
\hline A09 & IF GPS03 \& GPS18 THEN PS09 \\
\hline A10 & IF GPS01 \& GPS11 \& GPS12 THEN PS10 \\
\hline A11 & IF GPS1 \& GPS05 \& GPS13 \& GPS14 THEN PS11 \\
\hline A12 & IF GPS11 \& GPS15 THEN PS12 \\
\hline A13 & IF GPS01 \& GPS02 \& GPS05 THEN PS13 \\
\hline A14 & IF GPS05 \& GPS16 \& GPS17 THEN PS14 \\
\hline
\end{tabular}

C. Perancangan Use Case Diagram dan Activity Diagram

Use case diagram dibuat untuk mengetahui fungsi - fungsi didalam sebuah sistem yang dikembangkan. Use case diagram merepresentasikan interaksi antara actor dengan sistem. User bisa memulai diagnosa dengan cara menjawab pertanyaan dari sistem. User bisa melihat hasil diagnosis berdasarkan pertanyaan yang sudah dijawab.User bisa melihat seluruh daftar gejala penyakit sapi.User bisa melihat seluruh daftar penyakit sapi.User dapat melihat informasi terkait dengan penyakit.Use case diagram akan dijelaskan pada gambar 2 .

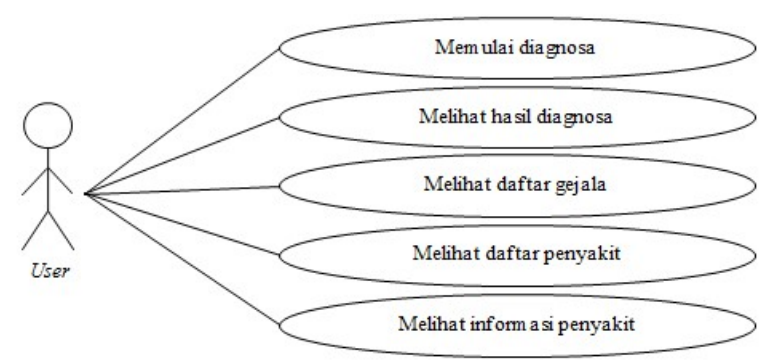

Gambar 2. Use Case Diagram

Activity diagram dibuat untuk memperjelas alur yang dilakukan user dalam sistem secara urut dan jelas. Activity diagram akan dijelaskan pada gambar 3.

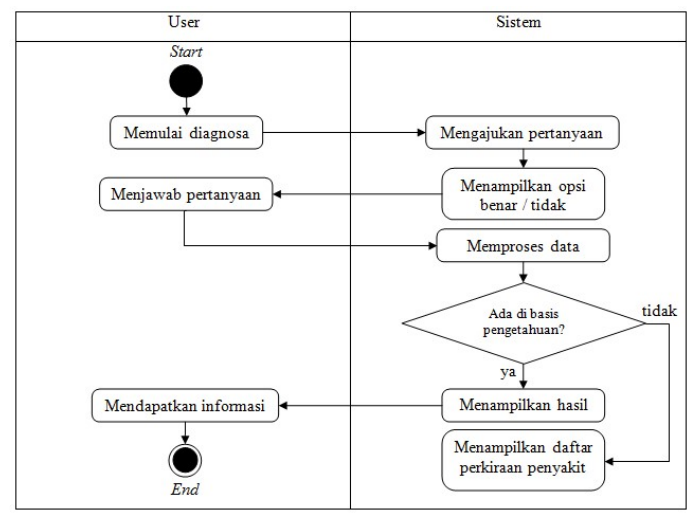

Gambar 3. Activity Diagram

\section{Hasil dan Pembahasan}

\section{A. Implementasi}

\section{1) Splash Screen}

Saat aplikasi dibuka maka userakan melihat halaman awal berupa Splash screen. Halaman ini tampil sebelum ke halaman utama aplikasi Dokter Sapi. Dalam halaman ini akan terdapat ProgressBaryang akan bergerak sampai angka persentase mencapai $100 \%$ dan selanjutnya akan masuk ke halaman utama aplikasi Dokter Sapi, untuk tampilan akan ditunjukkan pada gambar 4.

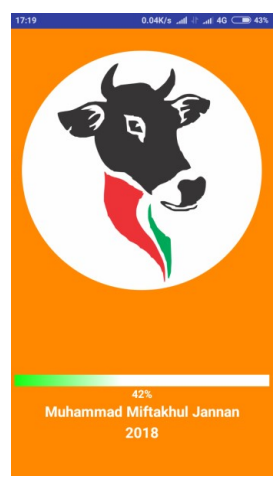

Gambar 4. Tampilan Splash screen

\section{2) Halaman Utama}

Halaman ini tampil setelah Splash screen.Pada halaman ini terdapat informasi singkat tentang aplikasi Dokter Sapi serta terdapat tombol DrawerToggle yang terletak di pojok kiri atas untuk melihat daftar menu navigasi yang terdiri dari mulai diagnosa untuk memulai memulai diagnosa penyakit sapi, menu data penyakit untuk melihat daftar data penyakit, menu data gejala untuk melihat daftar data gejala penyakit, untuk tampilan akan ditunjukkan pada gambar 5 .

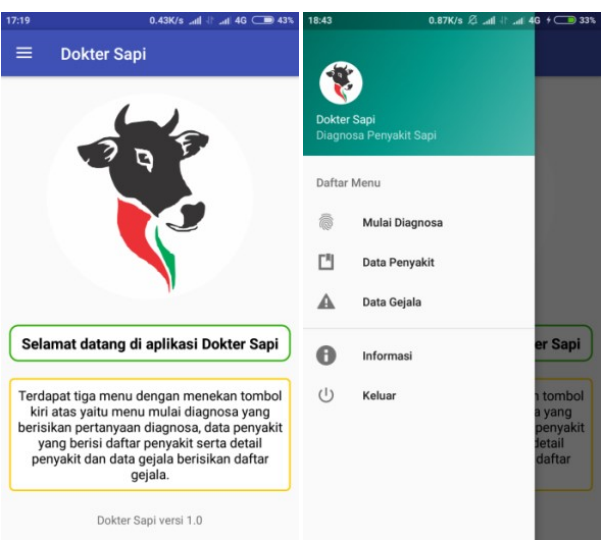

Gambar 5. Tampilan menu utama dan menu navigasi

\section{3) Halaman Mulai Diagnosa}

Halaman ini berisi tentang gejala - gejala penyakit sapi yang akan diajukan oleh sistem dan user cukup menjawab dengan menekan tombol "Benar" atau "Tidak". User akan dituntun dengan knowledge base sampai dengan penyakit yang 
diderita sapi berdasarkan jawaban yang diberikan. Untuk tampilan akan ditunjukkan pada gambar 6 .

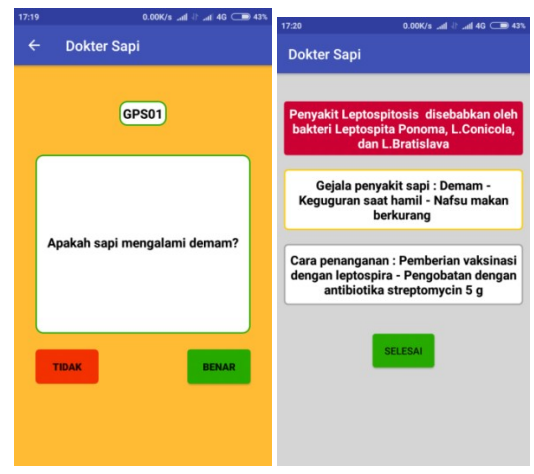

Gambar 6. Tampilan pertanyaan gejala dan hasil diagnosa

Aplikasi ini juga terdapat fitur perkiraan penyakit sebagai hasil diagnosa yang akan ditampilkan dalam bentuk ListViewsebanyak penyakit yang mirip. Pada ListView user dapat memilih penyakit yang diinginkan, selanjutnya akan ditampilkan informasi tentang penyakit yang dipilih. Untuk tampilan akan ditunjukkan pada gambar 7 .

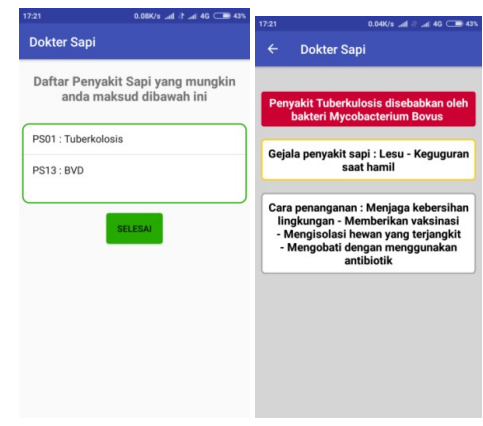

Gambar 7. Tampilan hasil perkiraan diagnosa dan informasi penyakit

\section{4) Menu Data Penyakit}

Halaman ini menampilkan daftar penyakit pada aplikasi ini. Terdapat 14 jenis penyakit yang akan ditampilkan dalam bentuk ListView. User dapat memilih sesuai keiinginan yang selanjutnya akan ditampilkan informasi tentang penyakit yang dipilih. Untuk tampilan akan ditunjukkan pada Gambar 8.

\section{5) Menu Data Gejala}

Halaman ini menampilkan daftar gejala penyakit pada aplikasi ini. Terdapat 18 gejala yang akan ditampilkan dalam bentuk ListView. User dapat memilih daftar gejala untuk melihat secara singkat informasi gejala yang dimaksud berupa gambar. Untuk tampilan akan ditunjukkan pada Gambar 9.

\section{6) Menu Informasi}

Halaman ini menampilkan penjelasan singkat tentang aplikasi dokter sapi. Untuk tampilan akan ditujunjukkan pada Gambar 10.

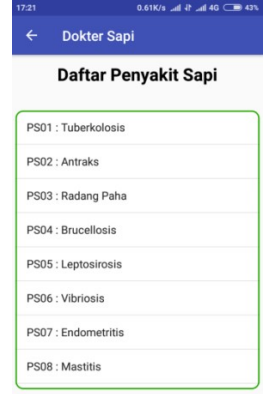

Gambar 8. Tampilan daftar penyakit
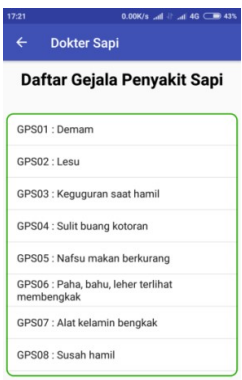

Gambar 9. Tampilan daftar gejala penyakit

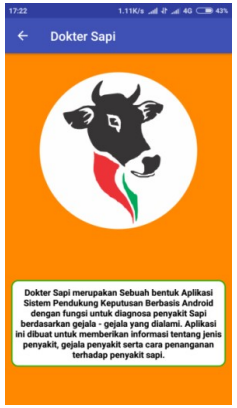

Gambar 10. Tampilan informasi aplikasi

\section{B. Pengujian}

\section{1) Pengujian Aplikasi}

Pengujian aplikasi menggunakan metode black box. Pengujian dilakukan untuk memastikan semua fitur yang dibuat sama dengan yang diharapkan oleh pengembang. Untuk hasil pengujian akan ditunjukkan pada Tabel 4.

\section{2) User Acceptance Test}

Pengujian dilakukan dengan cara menyebar kuisioner kepada 20 responden yang terdiri dari 15 peternak sapi, 2 dokter hewan dan 3 masyarakat umum. Dalam pengujian user dipersilahkan mencoba aplikasi dan selanjutnya mengisi kuisioner. Hasil pengujian akan ditunjukkan pada Tabel 5.

User Acceptance Test dapat dihitung dengan rumus :

Jumlah responden $=\mathrm{n}=20$

Nilai tertinggi $($ Smax $)=5 \times n=5 n(S S)$ 
Skor $(\mathrm{S})=\Sigma$ (Jumlah reponden yang menjawab $\times$ bobot jawaban)

$$
P=\frac{S \times 100 \%}{S \max }
$$

TABEL IV. PENGUJiAn BLACK BOX

\begin{tabular}{|c|c|c|c|}
\hline Input & Fungsi & Output & Hasil \\
\hline $\begin{array}{l}\text { Klik aplikasi } \\
\text { Dokter Sapi }\end{array}$ & $\begin{array}{l}\text { Membuka Aplikasi } \\
\text { Dokter Sapi }\end{array}$ & $\begin{array}{l}\text { Menampilkan } \\
\text { Splash Screen }\end{array}$ & Valid \\
\hline $\begin{array}{c}\text { Klik tombol } \\
\text { DrawerTogle } \\
\text { / navigasi }\end{array}$ & $\begin{array}{c}\text { Membuka } \\
\text { Drawertogle }\end{array}$ & $\begin{array}{c}\text { Menampilkan menu } \\
\text { navigasi }\end{array}$ & Valid \\
\hline $\begin{array}{l}\text { Klik menu } \\
\text { Mulai } \\
\text { Diagnosa }\end{array}$ & $\begin{array}{c}\text { Memulai pertanyaan } \\
\text { diagnosa }\end{array}$ & $\begin{array}{c}\text { Menampilkan } \\
\text { pertanyaan dengan } \\
\text { pilihan "Tidak" atau } \\
\text { "Benar" }\end{array}$ & Valid \\
\hline $\begin{array}{l}\text { Klik tombol } \\
\text { "BENAR" } \\
\text { atau } \\
\text { "TIDAK" }\end{array}$ & $\begin{array}{c}\text { Mengganti } \\
\text { pertanyaan dengan } \\
\text { pertanyaan } \\
\text { selanjutnya dan } \\
\text { memperoleh hasil } \\
\text { diagnosa } \\
\end{array}$ & $\begin{array}{c}\text { Menampilkan } \\
\text { pertanyaan } \\
\text { selanjutnya dan } \\
\text { mendapatkan hasil } \\
\text { diagnosa }\end{array}$ & Valid \\
\hline $\begin{array}{c}\text { Klik nama } \\
\text { penyakit pada } \\
\text { daftar prediksi } \\
\text { penyakit }\end{array}$ & $\begin{array}{c}\text { Membuka informasi } \\
\text { penyakit }\end{array}$ & $\begin{array}{c}\text { Menampilkan } \\
\text { informasi terkait } \\
\text { penyakit tersebut }\end{array}$ & Valid \\
\hline $\begin{array}{l}\text { Klik tombol } \\
\text { selesai }\end{array}$ & $\begin{array}{c}\text { Menutup halaman } \\
\text { dan kembali ke } \\
\text { halaman utama }\end{array}$ & $\begin{array}{c}\text { Kembali ke halaman } \\
\text { utama }\end{array}$ & Valid \\
\hline $\begin{array}{c}\text { Klik menu } \\
\text { Data Penyakit }\end{array}$ & $\begin{array}{c}\text { Membuka daftar } \\
\text { penyakit }\end{array}$ & $\begin{array}{c}\text { Menampilkan daftar } \\
\text { data penyakit }\end{array}$ & Valid \\
\hline $\begin{array}{c}\text { Klik nama } \\
\text { penyakit pada } \\
\text { daftar } \\
\text { penyakit sapi }\end{array}$ & $\begin{array}{l}\text { Membuka informasi } \\
\text { terkait yang dipilih }\end{array}$ & $\begin{array}{c}\text { Menampilkan } \\
\text { informasi terkait } \\
\text { penyakit yang } \\
\text { dipilih }\end{array}$ & Valid \\
\hline $\begin{array}{l}\text { Klik menu } \\
\text { Data Gejala }\end{array}$ & $\begin{array}{c}\text { Membuka daftar data } \\
\text { gejala }\end{array}$ & $\begin{array}{c}\text { Menampilkan daftar } \\
\text { data gejala }\end{array}$ & Valid \\
\hline $\begin{array}{c}\text { Klik nama } \\
\text { gejala pada } \\
\text { daftar gejala } \\
\text { penyakit sapi }\end{array}$ & $\begin{array}{c}\text { Membuka informasi } \\
\text { singkat gejala yang } \\
\text { dipilih }\end{array}$ & $\begin{array}{c}\text { Menampilkan } \\
\text { informasi terkait } \\
\text { gejala penyakit yang } \\
\text { dipilih }\end{array}$ & Valid \\
\hline $\begin{array}{l}\text { Klik menu } \\
\text { Informasi }\end{array}$ & $\begin{array}{c}\text { Membuka informasi } \\
\text { aplikasi }\end{array}$ & $\begin{array}{c}\text { Menampilkan } \\
\text { informasi tentang } \\
\text { aplikasi }\end{array}$ & Valid \\
\hline $\begin{array}{l}\text { Klik menu } \\
\text { keluar }\end{array}$ & Keluar dari aplikasi & $\begin{array}{l}\text { Menutup dari } \\
\text { aplikasi }\end{array}$ & Valid \\
\hline $\begin{array}{l}\text { Klik Back di } \\
\text { halaman } \\
\text { utama }\end{array}$ & Keluar dari aplikasi & $\begin{array}{l}\text { Menutup dari } \\
\text { aplikasi }\end{array}$ & Valid \\
\hline
\end{tabular}

Berikut contoh menghitung User Acceptance Test pertama yaitu tampilan aplikasi menarik.

Jumlah responden menjawab: $S S=6$ orang, $S=9$ orang, $\mathrm{KS}=0$ orang, TS $=5$ orang dan STS $=0$ orang, sehingga $\mathrm{n}=$ jumlah responden $=20$.

Berdasarkan persamaan (1), (2), (3) dan (4) maka diperoleh:

Nilai tertinggi $(\mathbf{S m a x})=5 \times \mathbf{n}=5 \times 20=100$

$\operatorname{Skor}(\boldsymbol{S})=\Sigma(\mathrm{SS}+\mathrm{S}+\mathrm{KS}+\mathrm{TS}+\mathrm{STS})=(5 \times 9)+(4 \times 9)+(3 \times 0)+$ $(2 \times 5)+(1 \times 0)=76$

$$
\boldsymbol{P}=\frac{\mathbf{7 6} \times \mathbf{1 0 0} \%}{\mathbf{1 0 0}}=76 \%
$$

Dari hasil User Acceptance Test menunjukkan bahwa aplikasi dapat diterima baik oleh user berdasarkan persentase nilai bervariasi dari yang paling rendah $76 \%$ hingga paling tinggi $89 \%$ dengan nilai rata - rata $80.6 \%$.

TABEl V. Hasil USER ACCEPTANCE TEST

\begin{tabular}{|c|c|c|c|c|c|c|c|c|}
\hline No. & Data & SS & S & KS & TS & SKS & $\begin{array}{c}\text { Jumlah } \\
\text { Skor }\end{array}$ & $\begin{array}{c}\text { Persen- } \\
\text { tase }\end{array}$ \\
\hline 1 & $\begin{array}{c}\text { Tampilan } \\
\text { aplikasi } \\
\text { menarik }\end{array}$ & 6 & 9 & 0 & 5 & 0 & 76 & $76 \%$ \\
\hline 2 & $\begin{array}{c}\text { Aplikasi } \\
\text { mudah } \\
\text { digunakan }\end{array}$ & 2 & 17 & 0 & 1 & 0 & 80 & $80 \%$ \\
\hline 3 & $\begin{array}{c}\text { Isi materi } \\
\text { mudah } \\
\text { dipelajari }\end{array}$ & 2 & 18 & 0 & 0 & 0 & 82 & $82 \%$ \\
\hline 4 & $\begin{array}{c}\text { Aplikasi } \\
\text { dapat } \\
\text { membantu } \\
\text { menentukan } \\
\text { penyakit }\end{array}$ & 4 & 12 & 0 & 4 & 0 & 76 & $76 \%$ \\
\hline 5 & $\begin{array}{c}\text { Aplikasi } \\
\text { bermanfaat }\end{array}$ & 9 & 11 & 0 & 0 & 0 & 89 & $89 \%$ \\
\hline \multicolumn{7}{|l}{ Rata - rata } \\
\hline
\end{tabular}

\section{Penutup}

Berdasarkan pengujian black box ini dapat disimpulkan bahwa aplikasi berjalan dengan baik dengan keluaran berbentuk penyakit yang diderita oleh sapi serta penanganannya. Aplikasi ini juga tergolong baik ditunjukkan dengan hasil pengujian User Acceptance Test dengan nilai rata - rata $80.6 \%$.

Dalam aplikasi ini terdapat beberapa keunggulan akan tetapi masih terdapat kekurangan, saran penulis untuk kedepannya untuk menambahkan informasi beserta dokumentasi berupa foto agar lebih mudah dipahami.

\section{Daftar Pustaka}

[1] Handayani, R. I. (2017). "Sistem Pendukung Keputusan Pemilihan Karyawan Berprestasi dengan Metode Profile Matching pada PT.Sarana Inti Persada (SIP)". Jurnal Pilar Nusa Mandiri, 13 (1), 28-34. ISSN: $1978-1946$.

[2] Hidayat, H. A., \& Gumilang G. (2017). "Sistem Pakar Diagnosis Penyakit Yang Disebabkan Oleh Rokok Dengan Metode Forward Chaining". Jurnal Teknik Informatika, 5(2), 1-10. ISSN: 2338 - 1477.

[3] Kapoor, N., \& Bahl, N. (2016). "Comparative Study of Forward and Backward Chaining in Artificial Intelegence. International Journal Of Enginering And Computer Science", 5(4), 16239 - 16242. ISSN: 2319 7242 .

[4] Katoua, H. S. (2014). "The Role of Artificial Intelligence in Environmental Decision Support Systems". International Journal of Computer and Information Technology, 3(5), 1011-1014. ISSN: 22790764 . 
[5] Rohman, A., \& Supriyono, H. (2018). "Sistem Pakar Diagnosa Penyakit Ikan Lele Berbasis Android" .The $7^{\text {th }}$ University Research Colloquium 2018 STIKES PKU Muhammadiyah Surakarta. 62 - 75.

[6] Supriyono, H., \& Sari, C. P. (2015). "Pemilihan Rumah Tinggal Menggunakan Metode Weighted Product". Khazanah Informatika, 1(1), 23-28. E-ISSN: 2477 - 6898X
[7] Yulianto, P., \& Saparinto, C.(2014). "Beternak Sapi Limousin". Jakarta: Penebar Swadaya". ISBN: 979 - 002 - 655 - 2. 